\title{
Progesterone Induces Cellular Differentiation in MDA-MB-231 Breast Cancer Cells Transfected with Progesterone Receptor Complementary DNA
}

\author{
Valerie Chun-Ling Lin, ${ }^{*}$ Rongxian Jin, ${ }^{\ddagger}$ \\ Puay-Hoon Tan, ${ }^{\dagger}$ Swee-Eng Aw, ${ }^{*}$ \\ Chow-Thai Woon, ${ }^{*}$ and Boon-Huat Bay ${ }^{\ddagger}$ \\ From the Departments of Clinical Research* and Pathology, ${ }^{\dagger}$ \\ Singapore General Hospital, Singapore; and the Department of \\ Anatomy, Faculty of Medicine, National University of Singapore, \\ Singapore, Singapore
}

Progesterone is an important regulator of growth and differentiation in breast tissues. In this study, the effect of progesterone on cell differentiation was evaluated in the estrogen receptor-negative and progesterone receptor (PR)-negative MDA-MB-231 cell line which was transfected with PR-complementary DNA. Morphological changes were analyzed at the ultrastructural level by scanning and transmission electron microscopy. Progesterone-treated PR-transfected cells exhibited a more protracted and well spread morphology with an increase in organelles such as mitochondria and rough endoplasmic reticulum as compared to the rounded form of control vehicle ( $0.1 \%$ ethanol)-treated PR-transfected cells. Vehicle and progesterone-treated MDA-MB231 cells transfected with the pSG5 plasmid (transfection control cells) had similar rounded morphology as control vehicle-treated PR-transfected cells. Immunofluorescence staining revealed that expression of E-cadherin, a differentiation marker, was more prominent in progesterone-treated cells. Expression of keratin and vimentin but not $\beta$-catenin was up-regulated in progesterone treated cells when evaluated by immunoblotting. As signal transducers and activators of transcription (STAT) molecules have been implicated in mammary differentiation, we analyzed the expression of Stat 1, 3, $5 \mathrm{a}$, and $\mathbf{5 b}$ proteins and found a significant up-regulation of the Stat $5 \mathrm{~b}$ protein in progesterone-treated cells. We have provided in vitro evidence of the close association of PR with differentiation in breast cancer. It is likely that the Stat $5 \mathrm{~b}$ protein may play a major role in progesterone-induced differentiation in breast cancer cells. (Am J Patbol 2003, 162:1781-1787)

Steroid hormones play pivotal roles in the development of the mammary gland. ${ }^{1}$ The requirement for progesterone in normal mammary gland lobular-alveolar development has been verified by the failure of normal breast devel- opment in mice lacking progesterone receptors. ${ }^{2}$ Progesterone binds to intracellular progesterone receptors (PR) which belong to the nuclear receptor superfamily of transcription factors. ${ }^{3}$ When activated, PR binds to progesterone responsive elements in promoters, stimulating gene transcription and enhancing proliferation and differentiation of normal breast epithelium. ${ }^{1}$ In a similar manner, steroid hormones could affect cancer risk by controlling cell division, differentiation and susceptibility. ${ }^{4}$

Progesterone has been reported to either potentiate growth, have no effect on or inhibit proliferation in breast cancer cells. ${ }^{5-9}$ There is also in vitro evidence that progesterone could induce cellular differentiation in breast cancer. In the PMC 42 breast cancer cell line, cells have been demonstrated to form hollow organoids in culture which are similar to in vivo breast structures, on stimulation by a combination of hormones including estrogen, progesterone, dexamethasone, insulin, and prolactin. ${ }^{10}$ Genes expressing CD9/MRPP-1 (motility-related protein 1), CD-59/protectin and desmoplakin (the products of which are associated with epithelial differentiation), were observed to be up-regulated in progestin-treated T 47D cells. $^{7}$

To delineate the specific effects of progesterone from estrogen, we have established an estrogen receptor (ER)-independent expression of PR by stable transfection of the PR CDNA into ER-negative and PR-negative MDAMB-231 breast cancer cells. ${ }^{8,9,11}$ We have previously observed that progesterone treatment of progesterone receptor transfected MDA-MB-231 human breast cancer cells induced morphological changes which are suggestive of cell differentiation. ${ }^{11}$ Progesterone-treated PRtransfected MDA-MB-231 cells became more protracted and showed increased expression of stress fibers and focal adhesion proteins such as talin and paxillin, representing increased focal contacts of cells. In this study, we evaluated the morphological changes at the ultrastructural level in progesterone-treated PR-transfected MDAMB-231 breast cancer cells. Expression of differentiation markers such as E-cadherin and keratin, and cytoskeletal

Supported by the National Medical Research Council, Singapore (grants 0430/2000 and 0612/2001)

Accepted for publication February 13, 2003.

Address reprint requests to Boon-Huat Bay, MBBS, Ph.D., Department of Anatomy, Faculty of Medicine, National University of Singapore, 4 Medical Drive, Blk MD10, S 117 597, Singapore. E-mail: antbaybh@nus.edu.sg. 
proteins such as $\beta$-catenin and vimentin were analyzed in vehicle-treated and progesterone-treated PR-transfected cells by immunofluorescent staining and Western blot analysis. To elucidate whether the differentiation process was mediated by signal transducers and activators of transcription (STAT) molecules, the levels of Stat 1, 3, and 5 proteins were determined.

\section{Materials and Methods}

\section{Cell Culture}

MDA-MB-231 cells, obtained from the American Type Culture Collection at passage 28, were cloned using a 96-well plate by the single-dilution method and clone 2 was selected for transfection studies. All of the cells were routinely maintained in DMEM supplemented with dextran charcoal-treated $5 \%$ fetal calf serum, $2 \mathrm{mmol} / \mathrm{L}$ glutamine and $40 \mathrm{mg} / \mathrm{L}$ gentamicin.

\section{Transfection of PR cDNA}

MDA-MB-231 cells were transfected with PR expression vectors hPR1 and hPR2 (which were generous gifts from Professor P. Chambon) as previously described. ${ }^{8,9,11}$ Vectors hPR1 and hPR2 contained human PR cDNA encoding $P R$ isoform $B$ and isoform $A$, respectively, in pSG5 plasmid. Vector pBK-CMV (Stratagene, La Jolla, CA) containing the neomycin-resistant gene was co-transfected with hPR1 and hPR2 into MDA-MB-231-CL2 cells. Neomycin-resistant clones were screened for PR using the PR enzyme immunoassay (EIA) kit (Abbott Laboratories, Abbott Park, IL). Clone ABC28 expressing 660 $\mathrm{fmol}$ PR per mg protein was used in this study. MDA-MB231 cells, which were stably transfected with both vectors pBK-CMV and pSG5 (clone pSG5-c15), served as transfection controls.

\section{Progesterone Treatment of Cells}

Cells were treated with $0.1 \mu \mathrm{mol} / \mathrm{L}$ progesterone or vehicle $(0.1 \%$ ethanol) for 24 to 72 hours. Progesterone was from a 1000-fold stock in ethanol.

\section{Scanning Electron Microscopy (SEM)}

Cells were grown on glass slides and fixed in 5\% glutaraldehyde in a $0.1 \mathrm{~mol} / \mathrm{L}$ cacodylate buffer $(\mathrm{pH}$ 7.2) as previously described. ${ }^{11}$ This was followed by osmication in $1 \%$ osmium tetroxide in the same buffer for 30 minutes. The cells were then dehydrated in increasing concentrations of methanol until absolute level before drying in the Balzers critical point dryer (Baltec, Fustentum Liechtenstein). All of the cells were coated with $20 \mathrm{~nm}$ of gold in a Balzers sputter coater (model SCD 004) and examined in a Philips SEM 515 scanning electron microscope (Eindhoven, Holland).

\section{Transmission Electron Microscopy (TEM)}

Cell cultures grown on chambered coverglass slides were fixed with $2 \%$ paraformaldehyde and $3 \%$ glutaraldehyde in $0.1 \mathrm{~mol} / \mathrm{L}$ of phosphate buffer $(\mathrm{pH} 7.4)$ for 30 minutes. This was followed by osmication in phosphatebuffered $1 \%$ osmium tetroxide for 1 hour at room temperature. After washing with deionized water, samples were dehydrated in an ascending series of ethanol and embedded in araldite. Ultrathin sections were cut, mounted on formvar-coated nickel grids and doubly stained with lead citrate and uranyl acetate before viewing in a Philips CM 120 transmission electron microscope.

\section{Immunofluorescence Staining}

Cells were grown on glass coverslips in six-well plates for 48 hours before receiving treatment with control vehicle ( $0.1 \%$ ethanol) or $0.1 \mu \mathrm{mol} / \mathrm{L}$ progesterone. After rinsing with phosphate-buffered saline (PBS), the cells were fixed in 4\% paraformaldehyde and permeabilized with $0.2 \%$ Triton $X-100$. This was followed by incubation with $2 \%$ fetal calf serum in PBS for 1 hour to block nonspecific binding. All of the subsequent incubations with antibodies were carried out in PBS containing $2 \%$ fetal calf serum. For co-immunostaining of F-actin and E-cadherin, mouse monoclonal antibody to E-cadherin (Transduction Laboratories, Lexington, KY) were incubated with the cells overnight at $4^{\circ} \mathrm{C}$, followed by incubation with Cy5conjugated anti-mouse IgG and FITC-phalloidin (Sigma, St. Louis, MO) at room temperature for 1 hour. After washing in PBS, the coverslips were mounted on slides with fluorescence mounting media from DAKO (Carpinteria, CA). Stained cells were viewed and photographed using the Zeiss confocal laser scanning microscope model LSM 510. The staining of E-cadherin was quantitated by counting the number of E-cadherin spots. Five fields were analyzed for both control and progesteronetreated cells. Each field contained 3 to 10 cells, and a total of 32 control and 24 progesterone-treated cells were analyzed

\section{Evaluation of Keratin, Vimentin, and $\beta$-Catenin Protein Expression}

The cells were lysed with $200 \mu$ l of cold lysis buffer (50 $\mathrm{mmol} / \mathrm{L}$ Hepes, $150 \mathrm{mmol} / \mathrm{L} \mathrm{NaCl}, 1 \%$ Triton $\mathrm{X}-100,5$ $\mu \mathrm{g} / \mathrm{ml}$ pepstatin A, $5 \mu \mathrm{g} / \mathrm{ml}$ leupeptin, $2 \mu \mathrm{g} / \mathrm{ml}$ aprotinin, 1 $\mathrm{mmol} / \mathrm{L}$ PMSF, $100 \mathrm{mmol} / \mathrm{L}$ sodium fluoride and $1 \mathrm{mmol} / \mathrm{L}$ sodium vanadate, $\mathrm{pH}$ 7.5). After standing on ice for 20 minutes, the protein supernatants were collected by centrifugation at $13,000 \times g$ for 20 minutes and the protein concentrations were determined using a protein assay kit (Bio-Rad). $20 \mu \mathrm{g}$ of the protein were analyzed for keratin, a mixture of clone $A E 1$ and $A E 3$ at a ratio of $4: 1$ (DAKO), vimentin (DAKO) and $\beta$-catenin (Transduction Laboratories) by Western blotting using the ECL detection kit 

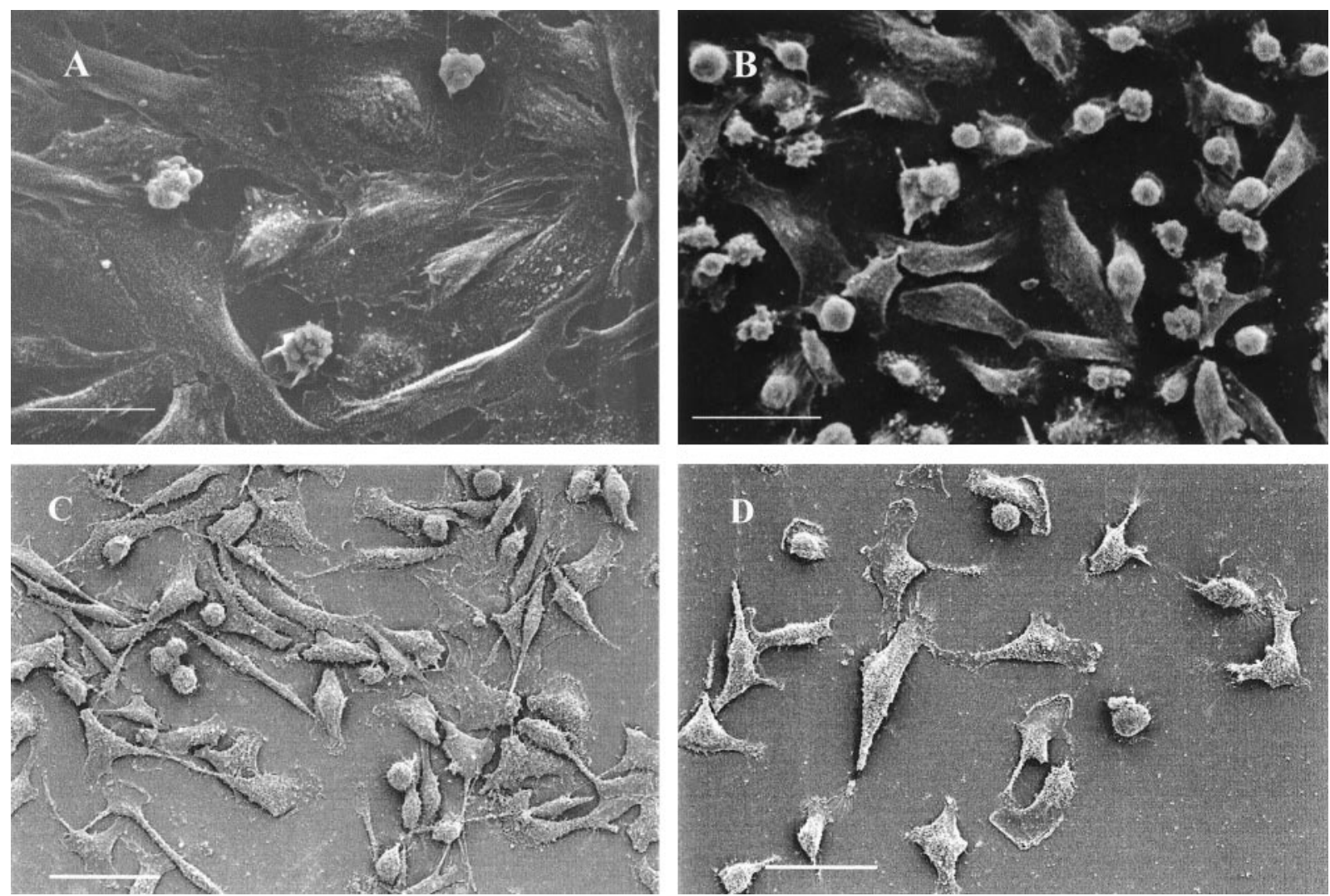

Figure 1. Scanning electron micrographs of progesterone-treated ABC28 (PR-transfected MDA-MB-231) cells (A) which are more flattened than vehicle- (0.1\% ethanol) treated ABC28 cells (B) after 48 hours of treatment. Bar, $30 \mu \mathrm{m}$. Progesterone-treated and vehicle-treated MDA-MB-231 cells transfected with the pSG5 plasmid ( $\mathbf{C}$ and $\mathbf{D}$, respectively) looked similar to vehicle treated ABC28 cells. Bar, $50 \mu \mathrm{m}$.

(Amersham Biosciences, Inc.). The Western blot experiments were done in duplicate.

\section{Statistical Analysis}

The GraphPad Prism software was used for analysis. Student's $t$-test was used to determine the significance in comparing means.

\section{Results}

\section{Morphological Changes at the Ultrastructural Level}

Progesterone-treated ABC28 cells (PR-transfected MDAMB-231 cells) appeared more flattened and well spread than vehicle-treated control cells at 24 hours of treatment. The round-to-flat change was much more obvious after 48 hours of progesterone treatment (Figure 1A and B). The vehicle-treated cells maintained a rounded morphology, had a smaller surface area and were more easily detachable from the substratum as compared to the flat, protracted progesterone-treated cells. Progesterone-treated and vehicle-treated MDA-MB-231 cells transfected with the pSG5 plasmid had a similar appearance to that of vehicletreated ABC28 cells (Figure 1, C and D). Transmission electron microscopy revealed the presence of more cyto- plasmic organelles such as rough endoplasmic reticulum and mitochondria in progesterone-treated ABC28 cells when compared with vehicle-treated ABC28 cells (Figure 2) and progesterone-treated or vehicle-treated transfection controls (not shown). Some of the progesterone-treated ABC cells showed the presence of bundles of tonofibrils after 48 hours of treatment (Figure 3). It is likely that these intermediate filaments represent keratin production. ${ }^{12}$

\section{Expression of E-Cadherin by Immunofluorescence Staining}

The E-cadherin staining in ABC28 cells appeared as aggregated spots. Minimal staining of the adhesion molecule E-cadherin was observed in vehicle-treated cells. There was an obvious increase in E-cadherin immunofluorescent staining in progesterone-treated cells, as compared with vehicle-treated controls cells (Figure 4A and $B)$. It was notable that the E-cadherin immunofluorescence was localized in the cytoplasm rather than on the plasma membrane. A mean of 23 E-cadherin staining spots was noted as compared to only 4 spots for control cells $(P<0.001)$. The staining in the nuclei may be non-specific as it was noted in both control and progesterone-treated cells. For negative control cells, no Ecadherin staining was evident. 

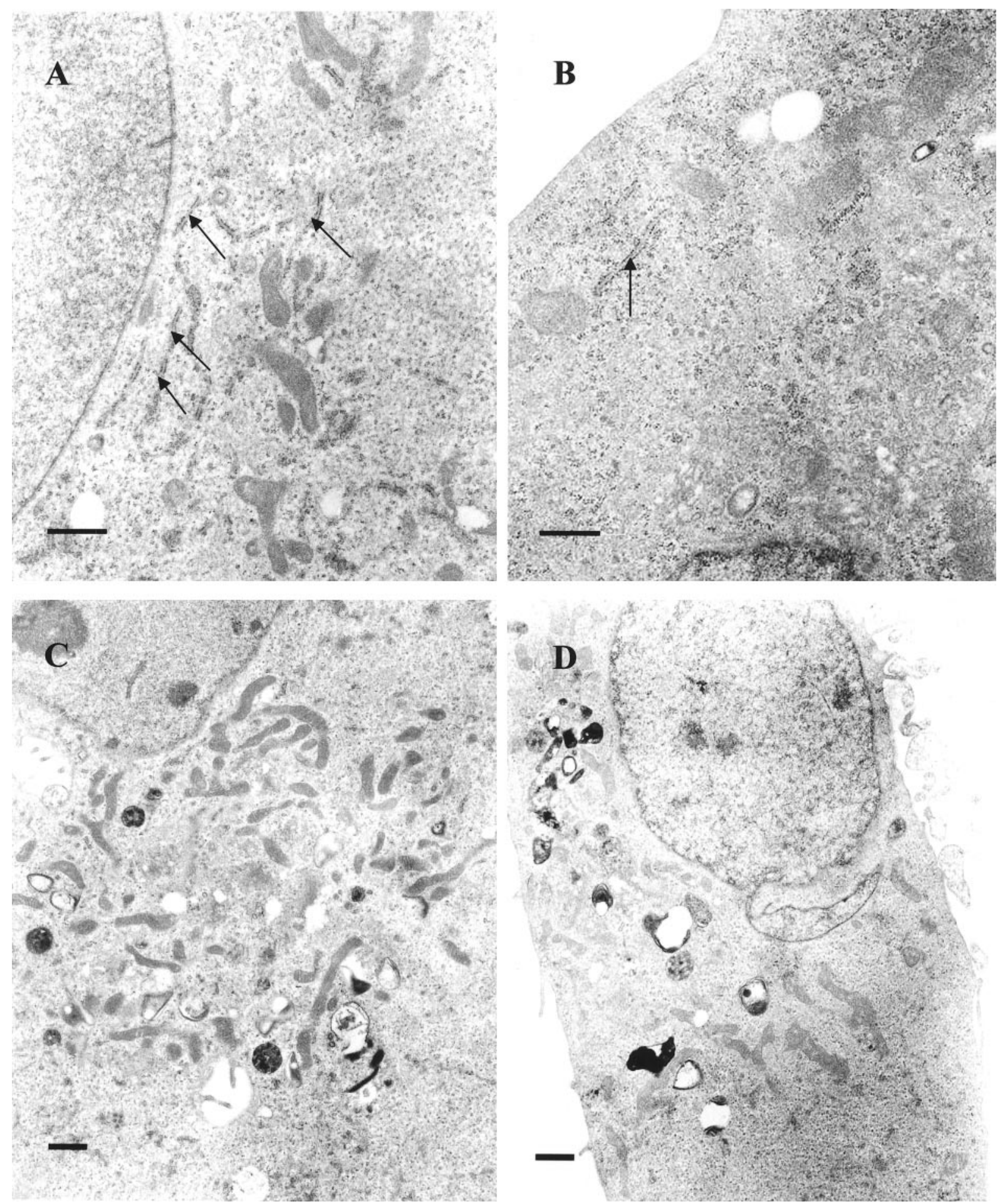

Figure 2. Transmission electron micrographs showing more rough endoplasmic reticulum (arrows) in progesterone-treated ABC28 cells (A) as compared to vehicle treated ABC28 cells (B) after 48 hours of treatment. Progesterone-treated ABC28 cells exhibited more mitochondria (C) than vehicle-treated controls (D). Bar, $1 \mu \mathrm{m}$.

\section{Expression of $\beta$-Catenin, Keratin, and Vimentin Proteins}

Figure 5 is a representative Western blot for $\beta$-catenin, keratin and vimentin. In progesterone-treated ABC28 cells, keratin and vimentin expression were enhanced by as much as 1.8-fold and 2.7-fold when evaluated at 72 hours, respectively. However, there was down-regulation of $\beta$-catenin expression in progesterone-treated cells by about $20 \%$ to $30 \%$. There was an increase of band intensity for $\beta$-catenin and keratin with time in the control cells. This may reflect the cellular response in terms of cell 


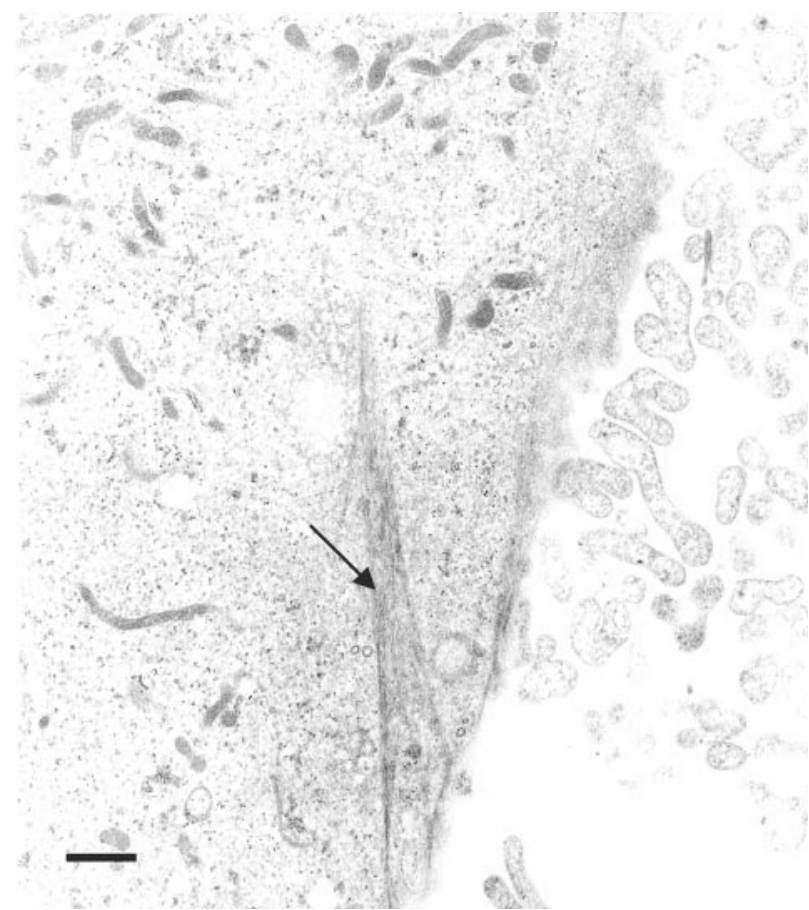

Figure 3. Transmission electron micrograph showing a progesterone-treated ABC28 cell with a bundle of tonofilaments after 48 hours of treatment (arrow). Bar, $1 \mu \mathrm{m}$.

density as both proteins are also involved in cell-cell adhesion.

\section{Expression of Stat 1, 3, 5a, and 5b Proteins}

Progesterone-treated ABC28 breast cancer cells showed a gradual time-dependent increase in Stat 1 expression by $19 \%$ to $37 \%$ as compared with vehicle-treated cells (Figure 6). The Stat 3 and Stat 5 a expression levels were fairly similar in both progesterone-treated and control cells. However, Stat 5b expression in progesteronetreated cells showed increased levels as early as 12 hours, increasing by 2.6-fold at 24 hours and more than fourfold by 48 hours.

\section{Discussion}

In the present study, a round-to-flat change of cell shape after progesterone treatment in ABC28 cells was shown by SEM whereas vehicle and progesterone-treated transfection control cells had the same rounded morphology as control ABC cells. TEM revealed that ABC28 cells treated with progesterone contained more organelles such as mitochondriae (which produce ATP via oxidative phosphorylation) and rough endoplasmic reticulum (which is important for protein synthesis), morphological changes which are regarded as a indicative of cell differentiation, ${ }^{13}$ as compared to vehicle-treated ABC28 cells and MDA-MB231 cells transfected with control vector.

This was further supported by the demonstration of differential expression of the cell adhesion molecule Ecadherin in control and progesterone-treated ABC28 cells. E-cadherin, a transmembrane glycoprotein which is localized in the adherens junctions of epithelial cells, is a calcium-dependent adhesion molecule which is critical in epithelial junction formation. ${ }^{14}$ E-cadherin expression is regarded as an epithelial cell differentiation marker. ${ }^{15,16}$ Reduction of E-cadherin expression has been related to loss of cellular differentiation and acquisition of invasive and metastatic potential in human head and neck tumors, ${ }^{17}$ breast cancer, ${ }^{18,19}$ bladder tumors, ${ }^{20}$ and gastric carcinoma. $^{21}$ Enhanced E-cadherin expression was demonstrated in progesterone treated ABC28 cells as compared with vehicle treated ABC28 cells. Although it has been reported that MDA-MB-231 cells (parental cells of $\mathrm{ABC} 28$ ) do not express E-cadherin, ${ }^{22}$ we observed minimal expression in the control ABC28 cells. Positive immunoreactivity of E-cadherin was localized in the cytoplasm rather than its normal location at the cell membrane in both control and progesterone-treated cells. Altered localization of E-cadherin has been previously observed in cervical cancers ${ }^{23}$ and esophageal tumors. ${ }^{24}$ The cytoplasmic localization of E-cadherin in the ABC28 cells may reflect the presence of abnormal and dysfunctional E-cadherin proteins (due to processes such as aberrant glycosylation), representing the malignant character of the cells. The presence of E-cadherin in the cytoplasm could also be due to the incapacity to
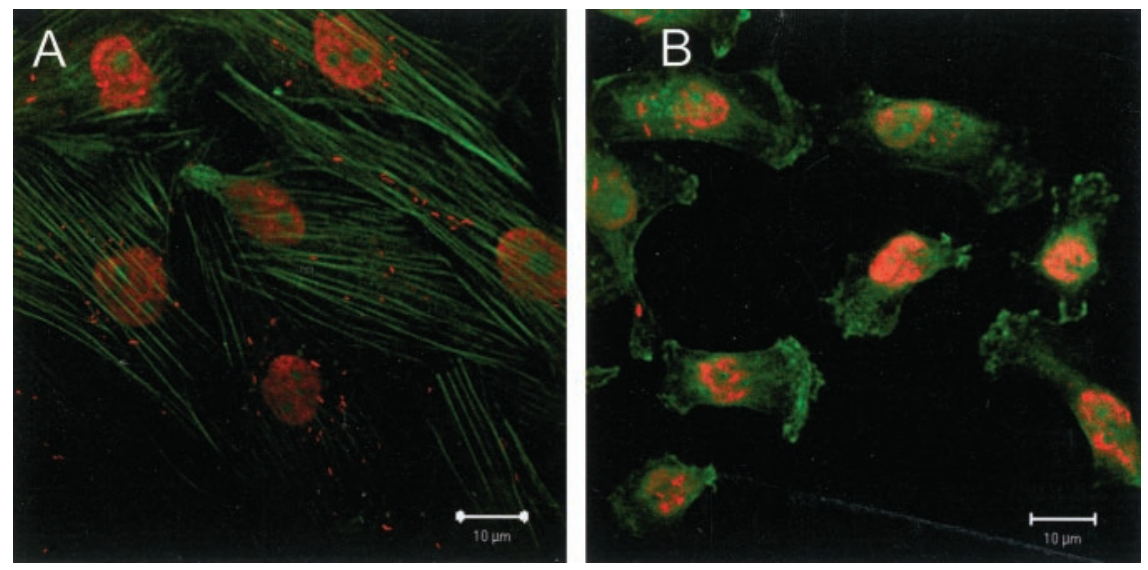

Figure 4. Immunofluorescent staining of adhesion protein E-cadherin (red) and F-actin (green) in $\mathrm{ABC} 28$ cells. Progesterone-treated cells (A) show prominent E-cadherin immunopositivity in the cytoplasm as compared with vehicle- treated cells (B) after 48 hours of treatment. Bar, $10 \mu \mathrm{m}$. 


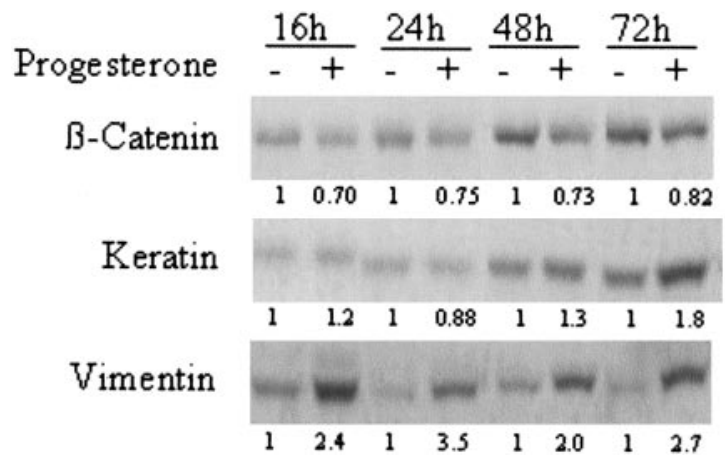

Figure 5. Effect of progesterone on $\beta$-catenin, keratin, and vimentin in ABC28 cells. Cells were treated with progesterone or control vehicle $(0.1 \%$ ethanol) for the periods of time as indicated. Whole cell lysate were collected and $20 \mu \mathrm{g}$ of protein was analyzed by Western blotting. Following detection of $\beta$-catenin, the membrane was stripped and re-probed sequentially with antibodies to keratin and vimentin respectively. The number below each lane indicates the relative density of the band signal when the corresponding control is given the value of 1 .

target the protein to the cell membrane after synthesis in the endoplasmic reticulum.

Increased keratin expression in progesterone-treated cells indicates the presence of more epithelial-like characteristics and may therefore support a more differentiated state. ${ }^{15}$ The presence of tonofilaments (intermediate filaments) observed under transmission electron microscopy in some ABC28 cells after 48 hours of treatment with progesterone is in accord with the Western blot findings. We also observed a decrease of $\beta$-catenin expression in progesterone-treated cells. $\beta$-catenin is a cytoplasmic protein that binds cadherins to the actin cytoskeleton during the assembly of cell-cell adherens junctions. ${ }^{25}$ Recent studies revealed that elevated levels of $\beta$-catenin have been associated with poor prognosis in human adenocarcinoma of the breast. ${ }^{26,27}$

This study has also provided direct evidence for the first time that vimentin is a progesterone-regulated protein in breast cancer cells. Vimentin, an intermediate filament which is present abundantly in fibroblasts, ${ }^{28}$ is

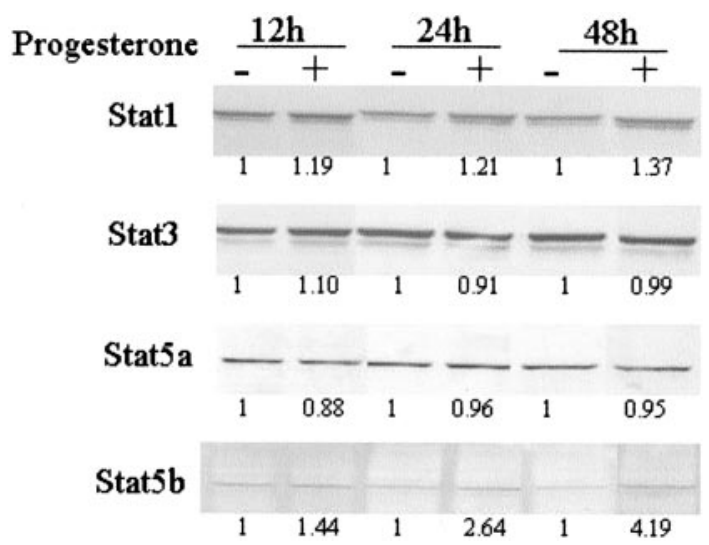

Figure 6. Effect of progesterone on protein levels of Stat 1, 3, 5a and 5b in ABC 28 cells. Cells were treated with progesterone or control vehicle $(0.1 \%$ ethanol) for the periods of time as indicated. Whole cell lysate were collected and $20 \mu \mathrm{g}$ of protein was analyzed by Western blotting. Following detection of Stat 3 with anti-Stat 3 monoclonal antibody, the membrane was stripped and re-probed sequentially with antibodies to Stat $5 \mathrm{a}$, Stat $5 \mathrm{~b}$ and Stat 1 , respectively. The number below each lane indicates the relative density of the band signal when the corresponding control is given the value of 1 . often associated with high-grade breast tumors. ${ }^{29}$ Contrary to our expectations, vimentin is up-regulated by progesterone in this cell line. It is known that there is pathway dysregulation as a result of gene mutations such as p53 in MDA-MB-231 cells $^{30,31}$; therefore, the up-regulation of vimentin observed here may reflect some additional uncoordinated events in this cell line rather than a physiological function of progesterone.

It is well known that cell differentiation is a complicated process, involving regulation of gene transcription, differential RNA processing and translation as well as intraand inter-cellular biomolecular regulation. ${ }^{32}$ Although the exact mechanism for the differentiated state of progesterone-treated $\mathrm{ABC}$ cells observed in this study is presently unclear, work by others has shown that progesterone activates signaling pathways involving mitogen-activated map kinase and members of the STAT family. ${ }^{33}$ STAT family members are known to regulate numerous genes involved in growth and differentiation. ${ }^{34}$ It is postulated that progesterone regulates STAT molecules by fostering proteinprotein interactions between PR and the STAT molecule, as well as up-regulating growth factor and cytokine receptors involved in STAT signaling. ${ }^{33}$ Of the 7 known mammalian STAT proteins, progestin treatment of breast cancer cells has been observed to regulate Stat 1,3,5a and $5 b$ in a PR-dependent manner in PR-positive T47D cells. ${ }^{35}$

We observed here that Stat 1 and Stat 5b were upregulated but not Stat 3 or Stat $5 a$ in progesteronetreated PR transfected MDA-MB-231 cells. Stat 1 has been associated with growth restraint and touted as a tumor suppressor. ${ }^{36-38}$ Hence the marginal increase in Stat 1 is consistent with our previous report that progestins inhibit growth of MDA-MB-231 cells transfected with PR complementary DNA. ${ }^{9}$ Stat 3 and 5 are known to play important roles in oncogenesis. Stat 5 comprises 2 genes, Stat $5 \mathrm{a}$ and $5 \mathrm{~b}$, with $96 \%$ homology and encoding two proteins, of which Stat $5 \mathrm{a}$ has seven more amino acids than Stat $5 b .{ }^{36}$ Although the molecular targets of Stat 5 are unknown, there is in vitro evidence of cytokine and cell-type specific utilization of Stat $5 a$ or Stat $5 b .{ }^{37,39}$

This study provides evidence of the association of PR with cell differentiation in an in vitro model. The in vitro model used in this study is useful for evaluating the specific effects of progesterone without the interference of estrogen. The observation of a differentiated breast cancer phenotype with progesterone treatment mediated by PR has clinical implications as a higher state of differentiation has been linked with lower metastasizing capacity. ${ }^{40}$

\section{Acknowledgments}

We thank Professor P. Chambon of the Institute of Genetics and Molecular and Cell Biology, Strasbourg, France, for kindly providing the progesterone receptor expression vectors hPR1 and hPR2. We also thank Dr. Chunhua Guo, Ms Joyce Leo, Ms Yee-Gek Chan, and Mr. ChunPeng Low for technical assistance. 


\section{References}

1. Russo J, Yu YF, Silva IDCG, Russo IH: Cancer risk related to mammary gland structure. Microsc Res Tech 2001, 52:204-223

2. Lydon JP, DeMayo FJ, Funk CR, Mani SK, Hughes AR, Montgomery CA Jr, Shyamala G, Conneely OM, O'Malley BW: Mice lacking progesterone receptor exhibit pleiotropic reproductive abnormalities. Genes Dev 1995, 9:2266-2278

3. Beato M, Herrlich P, Schutz G: Steroid hormone receptors: many actors in search of a plot. Cell 1995, 83:851-857

4. Key TJ: Hormones and cancer in humans. Mutat Res 1995, 333: $59-67$

5. Moore MR, Hathaway LD, Bircher JA: Progestin stimulation of thymidine kinase in the human breast cancer cell line T47D. Biochim Biophys Acta 1991; 1096:170-174

6. Kallkhoven E, Kwakkenbos-Isobruicker L, de Laat SW, Van der Saag PT, Van der Burg B: Synthetic progestins induce proliferation of breast tumor cell lines via the progesterone or estrogen receptor. Mol Cell Endocrinol 1994, 102:45-52

7. Kester HA, Van der Leede BM, Van der Saag PT, Van der Burg B: Novel progesterone target genes identified by an improved differential display technique suggest that progestin-induced growth inhibition of breast cancer cells coincides with enhancement of differentiation. J Biol Chem 1997, 272:16637-16643

8. Lin VCL, Ng EH, Aw SE, Tan MGK, Ng EHL, Chan VSW, Ho GH: Progestins inhibit the growth of MDA-MB-231 cells transfected with progesterone receptor complementary DNA. Clin Cancer Res 1999, 5:395-403

9. Lin VCL, Aw SE, Ng EH, Ng EHL, Chowdhury SH: Effect of progesterone on the invasive properties and tumor growth of progesterone receptor-transfected breast cancer cells MDA-MB-231. Clin Cancer Res 2001, 7:2880-2886

10. Ackland ML, Michalczyk A, Whitehead RH: PMC42, a novel model for the differentiated breast. Exp Cell Res 2001, 263:14-22

11. Lin VCL, Ng EH, Aw SE, Tan MGK, Ng EHL, Bay BH: Progesterone induces focal adhesion in breast cancer cells MDA-MB-231 transfected with progesterone receptor cDNA. Mol Endocrinol 2000, 14: 348-358

12. Ross MH, Romrell LJ, Kaye Gl: Histology: a text and atlas. $3^{\text {rd }}$ edn. Baltimore, Williams \& Wilkins, 1995, pp 373-374

13. Sacchi TB, Bani D, Brandi ML, Falchetti A, Bigazzi M: Relaxin influences growth, differentiation and cell-cell adhesion of human breastcancer cells in culture. Int J Cancer 1994, 57:129-134

14. Shirayoshi Y, Okada TS, Takeichi M: The calcium-dependent cell-cell adhesion system regulates inner cell mass formation and cell surface polarization in early mouse development. Cell 1983, 35:631-638

15. Sommers CL, Byers SW, Thompson EW, Torri JA, Gelmann EP: Differentiation state and invasiveness of human breast cancer cell lines. Breast Cancer Res Treat 1994, 31:325-335

16. Grunberg E, Eckert K, Karsten U, Maurer HR: Effects of differentiation inducers on cell phenotypes of cultured nontransformed and immortalized mammary epithelial cells: a comparative immunocytochemical analysis. Tumor Biol 2000, 21:211-223

17. Schipper JH, Frixen UH, Behrens J, Unger A, Jahnke K, Birchmeier W: E-cadherin expression in squamous cell carcinomas of head and neck: inverse correlation with tumor dedifferentiation and lymph node metastasis. Cancer Res 1991, 51:6328-6337

18. Oka H, Shiozaki $\mathrm{H}$, Kobayashi $\mathrm{K}$, Inoue $\mathrm{M}$, Tahara $\mathrm{H}$, Kobayashi $\mathrm{T}$, Takatsuka Y, Matsuyoshi N, Hirano S, Takeichi M: Expression of E-cadherin cell adhesion molecules in human breast cancer tissues and its relationship to metastasis. Cancer Res 1993, 53:1696-1701

19. Guriec N, Marcellin L, Gairard B, Calderoli H, Wilk A, Renaud R, Bergerat JP, Oberling F: E-cadherin mRNA expression in breast carcinomas correlates with overall and disease-free survival. Invasion Metastasis 1996, 16:19-26
20. Shimazui T, Schalken JA, Giroldi LA, Jansen CF, Akaza H, Koiso K, Debruyne FM, Bringuier PP: Prognostic value of cadherin-associated molecules $(\alpha-, \beta$-, and $\gamma$-catenins and p120cas) in bladder tumors. Cancer Res 1996, 56:4154-4158

21. Jawhari A, Jordan S, Poole S, Browne P, Pignatelli M, Farthing MJ: Abnormal immunoreactivity of the E-cadherin-catenin complex in gastric carcinoma: relationship with patient survival. Gastroenterology 1997, 112:46-54

22. Asgeirsson KS, Olafsdottir K, Jonasson JG, Ogmundsdottir HM: The effects of IL-6 on cell adhesion and e-cadherin expression in breast cancer. Cytokine 1998, 10:720-728

23. Vessey CJ, Wilding P, Folarin N, Hirano S, Takeichi M, Soutter P, Stamp GW, Pignatelli M: Altered expression and function of E-cadherin in cervical intraepithelial neoplasia and invasive squamous cell carcinoma. J Pathol 1995, 176:151-159

24. Khare L, Sabourin CL, De Young BR, Jamasbi RJ, Stoner GD: Altered localization of E-cadherin and $\alpha$-catenin in rat esophageal tumors. Int J Oncol 1999, 14:33-40

25. Sadot E, Geiger B, Oren M, Ben-Ze'ev A: Down-regulation of $\beta$-catenin by activated p53. Mol Cell Biol 2001, 20:6768-6781

26. Charpin C, Bonnier P, Garcia S, Andrac L, Crebassa B, Dorel M, Lavaut MN, Allasia C: E-cadherin and $\beta$-catenin expression in breast medullary carcinomas. Int J Oncol 1999, 15:285-292

27. Lin SY, Xia W, Wang JC, Kwong KY, Spohn B, Wen Y, Pestell RG, Hung MC: $\beta$-catenin, a novel prognostic marker for breast cancer: its roles in cyclin D1 expression and cancer progression. Proc Natl Acad Sci USA 2000, 97:4262-4266

28. Fawcett DW, Jensh RP: Bloom \& Fawcett's concise histology, ed 2. London, Arnold, 2002, pp 15-18

29. Seshadri R, Raymond WA, Leong AS, Horsfall DJ, McCaul K: Vimentin expression is not associated with poor prognosis in breast. Int $J$ Cancer 1996, 67:353-356

30. Megha T, Ferrari F, Benvenuto A, Bellan C, Lalinga AV, Lazzi S, Bartolommei S, Cevenini G, Leoncini L, Tosi P: p53 mutation in breast cancer. Correlation with cell kinetics and cell of origin. J Clin Pathol 2002, 55:461-466

31. Jones CB, Clements MK, Redkar A, Daoud SS: UCN-01 and camptothecin induce DNA double-strand breaks in p53 mutant tumor cells, but not in normal or p53 negative epithelial cells. Int J Oncol 2000, 17:1043-1051

32. Gilbert SF: Dev Biol, ed 5. Massachusetts, Sinauer Associates, Inc. 1997, pp 391-504

33. Lange C, Richer JK, Horwitz KB: Hypothesis: progesterone primes breast cancer cells for cross-talk with proliferative or antiproliferative signals. Mol Endocrinol 1999, 13:829-836

34. Darnell JE Jr: STATS and gene regulation. Science 1997, 277:16301635

35. Richer JK, Lange C, Manning G, Owen G, Powell R, Horwitz KB: Convergence of progesterone with growth factor and cytokine signaling in breast cancer. J Biol Chem 1998, 273:31317-31326

36. Bromberg JF: Activation of STAT proteins and growth control. Bioessays 2001, 23:161-169

37. Mui A L-F: The role of STATs in proliferation, differentiation, and apoptosis. Cell Mol Life Sci 1999, 55:1547-1558

38. Kaplan DH, Shanjaran V, Dighe AS, Stockert E, Aguet M, Old LJ, Schreiber RD: Demonstration of an interferon $\gamma$-dependent tumor surveillance system in immunocompetent mice. Proc Natl Acad Sci USA 1998, 95:7556-7561

39. Al-Shami A, Mahanna W, Naccache PH: Granulocyte-macrophage colony-stimulating factor-activated signaling pathways in human neutrophils: selective activation of Jak2, Stat3, and Stat 5b. J Biol Chem 1998, 273:1058-1063

40. Behrens J: Cell contacts, differentiation and invasiveness of epithelial cells. Invasion Metastasis 1994, 14:61-70 